\title{
Spatial Urban-Rural Interaction Patterns in Metropolitan Cirebon Raya using Remote Sensing and Socioeconomic Data
}

\author{
Zahrul Atharinafi ${ }^{\bullet}$ and Nurrohman Wijaya ${ }^{2}$
}

Corresponding author.・Email: zahrul3@yahoo.com

Submitted: 2021-11-24| Accepted: 2021-12-15| Published: December $31^{\text {st }} 2021$

\begin{abstract}
Urbanization patterns in developing Asian countries may or may not follow commonly known urbanization patterns and models set forth by lessons from the developed world. A unique phenomenon described as desakota is well known as a unique artifact of Asian urbanization, in which new urban areas arise semi-independently from otherwise rural regions in proximity to the edges of contiguous urbanized areas. We intend to identify the interaction between the urban fringe and surrounding rural areas while taking unique socioeconomic and morphological characteristics of the Desakota into account. We utilize a combination of $\mathrm{K}$ - Means Clustering, factor analysis, and spatiotemporal analysis to identify patterns of urbanization in Metropolitan Cirebon Raya, an industrializing metropolitan statistical region where agriculture is still a dominant land use, around Cirebon City, using statistical socioeconomic and demographic data from Badan Pusat Statistik in addition to land use data obtained from Landsat. Between 2010 - 2020, we identified substantial desakota type growth, in which new urbanized land development occurred organically from a formerly rural area, weakly linked to the supposed 'center' of the specified metropolitan region (Metropolitan Cirebon Raya). Based on the results obtained, we were able to corroborate desakota theory through quantitative methods, by taking socioeconomic and demographic data into account as a supplement to land use data. For delineation of metropolitan regions in Southeast Asia in which desakota patterns of development are presumed, we recommend utilizing the methodology we have developed, integrating both socioeconomic and demographic data to better identify desakota regions in peri-urban regions.
\end{abstract}

Keywords: Urban-rural linkages; peri-urbanization; remote sensing; factor analysis; KMeans Clustering.

\footnotetext{
${ }^{1}$ School of Architecture, Planning \& Policy Development, Bandung Institute of Technology
}

${ }^{2}$ School of Architecture, Planning \& Policy Development, Bandung Institute of Technology 


\section{Introduction}

\subsection{Background and Motivation}

Proper identification of urban-rural interaction patterns is an important aspect of urban and regional development planning, especially for districts that lie on the periphery of a greater urbanized region, the peri-urban areas. Industrialization - driven urbanization is a known driver of economic growth for developing countries. Hodder (2000), argues that agriculture depends on manufactured products for input (machinery, tools) and consumer goods, the demand of which increases as agricultural incomes rise. As agriculture incorporates more technology into its activities, labor becomes a less significant factor; labor becomes increasingly automated, thereby freeing rural labor to move into the urban industrial sector, fueling industrialization. In turn, industrialization can further increase agricultural incomes as agriculture provides raw materials for industrial purposes, such as tobacco. With this in mind, Mutizwa-Mangiza (1999), working for UNCHS, argues that promoting urban-rural linkages in development must offer considerable potential for developing the entire urban-rural continuum. That said, Mutizwa-Mangiza (1999) outlined steps regional planners must take to achieve such benefits. In particular, by strengthening urban-rural linkages, through the improvement of infrastructure necessary for marketing, communication, and transportation requirements needed to bring agricultural goods to processors in cities.

The move from agricultural activities to industrial, urban activities is in itself a critical component of a countries' economic development, following Rostow's Stages of Growth model (1960), which to this day, still stands for most cases (Costa et al., 2016). In more recent times, however, the importance of public infrastructure cannot be ignored. In separate studies, Lewis (2014) and Hassan \& Pitoyo (2016) both pointed out that, while urbanization has contributed somewhat towards Indonesia's economic growth, they also find out that poor public infrastructure has hindered the effect of urbanization on economic growth, with economic growth rates lagging behind urbanization rates. In such a case, Lewis (2014) even argues that rapid urbanization in Indonesia to be detrimental, when public infrastructure development is unable to keep up with urbanization.

Lynch (2005) provides a solid foundation for further study upon the various methods one can utilize to identify and understand urban-rural linkages. Lynch (2005) divides urbanrural linkages into several components: food, natural/environmental flows, people (migration and social networks), ideas, and financial (cash flows). Within the aforementioned components are supporting subcomponents that influence the urban-rural linkage, which are infrastructure networks between the city and its rural hinterland. In particular, transportation, marketing, and communication infrastructure are considered to be necessary to efficiently market food and bring rural migrants to the city and transfer wealth from cities into the hands of rural, agricultural producers.

Lynch (2005) provides a solid foundation for further study upon the various methods one can utilize to identify and understand urban-rural linkages. Lynch (2005) divides urbanrural linkages into several components: food, natural/environmental flows, people (migration and social networks), ideas, and financial (cash flows). Within $\mathrm{n}$ aforementioned components are supporting subcomponents that influence the urban-rural linkage are infrastructure networks between the city and its rural hinterland. In particular, transportation, marketing, and communication infrastructure is needed to efficiently market food and bring rural migrants to the city, and transfer wealth from cities into the hands of rural, agricultural producers.

Something to consider within the context of Indonesia (and other densely populated Asian countries) is the existence of desakota. First conceptualized by McGee (1991), desakota are typically situated outside the commuting range from city centers, outside the 
peri-urban zone. Desakota is characterized by a combination of high population density and intensive agriculture, differing from densely populated rural areas from the presence of urban-like characteristics, such as well-developed transportation networks, high population mobility, increased activity outside the agricultural sector, and unregulated land use (McGee, 1991).

Measuring urban-rural linkages via qualitative or mixed-method analysis is fine and allows for deeper insights into the urban-rural linkage and processes occurring within the urban-rural continuum (Qadeer, 2000; Olsson, 2012; Kim, 2015), yet requires a sizeable amount of time and effort that is impractical for many non-academic practitioners working on limited budgets and time. For this reason, various empirical methods have been developed over the years to explore urban-rural linkages directly, such as food distribution chains (Setyono, 2011; Setiadi et al., 2020), movements of labor (McGranahan \& Satterthwaite, 2014) Indirect methods are possible, among which include econometric analysis (Bao et al., 2004), qualitative, spatial analysis on socioeconomic data (Li, 2012; Budiyantini \& Pratiwi, 2016) or by analyzing changes in urban/land use morphology (Surya et al., 2020).

As for practical applications of measuring and understanding urban-rural linkages, within the context of Indonesia's planning system, might have its applications in local development planning, particularly in peri-urban and semi-rural regencies at the fringes of large metropolitan regions. It also has its uses in feasibility and environmental impact studies, especially for infrastructure projects aiming to improve the connection between urbanized areas with its rural hinterland (Surya et al., 2020, presents a direct use case of a methodology that can be directly implemented in regional land use and development planning).

For urban and regional planning practitioners, spatial analysis of urban-rural linkages (Xie et al., 2005, Li, 2012; Budiyantini \& Pratiwi, 2016; Surya et al., 2021) appears to hold promise as a quick, replicable method to identify urban-rural linkages. However, we believe that there is room for improvement in this sector. Li (2012) analyzed spatial urbanrural linkages at a provincial level, with the municipality (equivalent to a regency in Indonesia in size) being the smallest administrative unit being analyzed. A zoomed-in, detailed perspective with a larger scaled map (ie. Kecamatan - level) would perhaps be more appropriate for Indonesian urban and rural planning practitioners creating development plans at regency scale, for example. Budiyantini \& Pratiwi (2016) did analyze urban-rural linkages in a spatial dimension, but only used data from one time period and were only able to classify regions (Kecamatan) into clusters of urban, peri-urban, and rural classifications. Spatial analysis of land-use changes and urban sprawl holds promise (Surya et al., 2021), but ignores socioeconomic conditions and especially the premise of the desakota (McGee, 1991), in which urbanization might often occur independently of land-use changes, as people change professions from agricultural work to industrialized work as a result of economic diversification in the area (Moench \& Gyawali, 2008).

\subsection{Research Question}

Based on the aforementioned background, we have a few research questions in mind, which we will attempt to answer in this study. How can we identify and understand urbanrural linkages with available socioeconomic and remote sensing data? What does it imply? How can the results be translated into actionable land use or development planning policies?

\subsection{Thesis Statement}

In any case, we aim to create a replicable methodology to understand and identify urban-rural linkages for urban planning practitioners in Indonesia using readily available socioeconomic data from Badan Pusat Statistik (BPS) and remote sensing data from Landsat. Through the usage of socioeconomic data, we can uncover characteristic desakota 
urbanization patterns that would otherwise not be apparent from an urban morphology perspective, as desakota urbanization does not necessarily induce land development.

\subsection{Novelty}

In this study, we attempt to identify urban-rural interaction patterns in Indonesia, aiming to improve upon the works of Li (2012), Budiyantini \& Pratiwi (2016), and Surya et al., (2021). Here, we combine elements from each study methodology based on k-means clustering of socioeconomic data, similar to Budiyantini \& Pratiwi (2016), but utilize growth rates/temporal changes in the data as in Li (2012) and Surya et al., (2021). Whereas Budiyantini \& Pratiwi (2016) were limited to a one-time frame, by using growth rates as the unit of analyses, we instead identify a continuum of growth characteristics more akin to that of $\mathrm{Li}$ (2012). In addition, we are then able to factor in the element of land-use change as in Surya et al., (2021) into the analysis, versus only analyzing a snapshot of land use at a certain date.

\subsection{Study Area}

Our study focuses on an area as defined to be part of the "Metropolitan Cirebon Raya" sub delineation of the West Java province, according to Peraturan Daerah 12/2012. Our study area includes the regencies of Majalengka, Indramayu, Cirebon and Kuningan, as well as Kota Cirebon, the theoretical urban center of Metropolitan Cirebon Raya. The Cirebon Metropolitan Region is bordered by the Java Sea to the north, bordered by the regencies of Garut, Sumedang, Ciamis to the south, Central Java to the east, and Kabupaten Subang to the west.

In a greater regional context, the Cirebon Metropolitan Region is part of the Rebana industrial growth district. According to the Metropolitan Cirebon - Patimban - Kertajati action plan (BAPPEDA Jawa Barat, 2020), the Cirebon Metropolitan Region is a potentially industrializing area bounded by two growth driving infrastructure projects/logistics hubs the Kertajati Airport and Patimban Seaport, with a primary focus on attracting large scale industrial investments to Majalengka (Kertajati \& Jatiwangi) and near toll road exits in Indramayu (Cipali - Indramayu).

\section{Methodology}

\subsection{Methods}

Our methodology derives primarily from approaches and lessons learned in $\mathrm{Li}$ (2012), Budiyantini \& Pratiwi, and Surya et al., (2021), while also taking into account other literature with relatively similar methodological approaches. From Li (2012) and Budiyantini \& Pratiwi (2016), we use a combination of socioeconomic, demographic, and land cover data as variables in our study. An improvement upon Budiyantini \& Pratiwi (2016), following upon $\mathrm{Li}$ (2012) \& Surya et al. (2021), we intend to utilize the rate of growth in 10 years between 2010 and 2020 as our analytical basis. By using the rate of growth as a medium, we expect to classify regions based on their growth (or degrowth) rather than their status as urban, peri-urban, or rural. This allows us to better describe the linkages between urban (and increasingly urban) areas with their peri-urban and rural surroundings.

As in $\mathrm{Li}$ (2012), we perform a factor analysis of selected variables to obtain factor scores of possible underlying factors not represented by observed variables. K-means clustering is also performed, creating classifications based on a subdistrict's growth. Unlike $\mathrm{Li}$ (2012), studying on a larger regional scale; here we utilize a smaller, kecamatan - level that is more relevant for practicing urban and regional planners in Indonesia, intending to identify urban-rural linkages through quantitative methods. Identification of urban-rural 
linkages is therefore derived from evaluating the results of K-Means Clustering and factor scoring.

We utilize socioeconomic and demographic data from the Badan Pusat Statistik branches of each Kabupaten/Kota in our study area. Land use data is obtained from Landsat 7 (2010) and Landsat 8, processed through Google Earth Engine (GEE) following Sidhu et al. (2018) and Phan et al. (2020) to obtain data for built-up area percentage per subdistrict.

\subsection{Selected Variables}

Selected variables selected for this study are as such, from our study of previous relevant literature, according to the following Table 1 :

Table 1. Selected Variables in this Study

\begin{tabular}{|l|l|}
\hline Variable & Source \\
\hline Population Density & $\begin{array}{l}\text { (Pryor, 1968; Yunus, } \\
2006)\end{array}$ \\
\hline Percentage of Built-up Area & (Li, 2012) \\
\hline Gross Regional Product & (Pryor, 1968; Li, 2012) \\
\hline Dependency Ratio & (Pryor, 1968) \\
\hline School Accessibility Index & (Smailes, 1981) \\
\hline Health Accessibility Index & (Smailes, 1981) \\
\hline Percentage of Non-Farm Labor & (Li, 2012) \\
\hline Unemployment Rate & $\begin{array}{l}\text { (Pryor, 1968; Yunus, } \\
\text { 2006) }\end{array}$ \\
\hline
\end{tabular}

Source: Derived from Buidyantini \& Pratiwi (2016)

Unfortunately for us, Badan Pusat Statistik as of 2020 no longer publishes sufficient data for calculating the percentage of non-farm labor, with data only available for 2015 and prior. As a result, we elected to not proceed with utilizing the percentage of non-farm labor as an alternative proxy for urbanization, despite its great potential to identify desakota phenomena in which urbanization has occurred without significant expansion (McGee, 1991).

Badan Pusat Statistik does not publish GRP at the kecamatan scale, but we can create a usable proxy for calculating kecamatan scaled GRP following Fajar (2014). 


\section{Results, Analysis, and Discussions}

\subsection{Factor Analysis}

First, we perform a factor analysis to reduce variables into underlying factors that might describe the data we have and also provide a factor scoring mechanism that can be translated into spatial form and analyzed spatially. We use a trial and error based method (UCLA Statistical Consulting Group, 2020), iteratively changing parameters and processes until a satisfactory factor analysis is accomplished from the results of a Kaiser-Meyer-Olkin test (Hill, 2011) and a Pearson's Correlation Plot (Revelle, 2021a) to eliminate unrelated variables, and a scree plot to visually determine the number of factors being predicted, analyzed and scored (Cattell, 1966). Factor Analysis was performed in RStudio primarily using the psych package (Revelle, 2021b), the Hmisc (Harrell, 2021), and complot (Wei \& Simko, 2021 ) packages for analyzing the Pearson's Correlation Matrix of our data, and the factoextra (Kassambra, 2020) package for computing a scree plot of factors. By default, the psych package by default performs a Principal Axis Factoring (PAF) analysis (Revelle, 2021a), which we keep due to the non-normally distributed nature of our data (Fabrigar et al., 1999)

Table 2. Kaiser - Meyer - Olkin results

\begin{tabular}{|l|l|}
\hline Variable & MSA \\
\hline Overall MSA & 0.67 \\
\hline Population Growth & 0.62 \\
\hline Population Density Growth & 0.65 \\
\hline $\begin{array}{l}\text { GRP growth } \\
\text { Dependency Ratio }\end{array}$ & 0.62 \\
\hline $\begin{array}{l}\text { High School Accessibility (Growth, pct } \\
\%\end{array}$ & 0.71 \\
\hline $\begin{array}{l}\text { Middle School Accessibility (Growth, } \\
\text { pct \%) }\end{array}$ & 0.75 \\
\hline $\begin{array}{l}\text { Health Clinic Accessibility (Growth, pct } \\
\%\end{array}$ & 0.6 \\
\hline \begin{tabular}{l} 
High School Accessibility (Delta) \\
\hline Middle School Accessibility (Delta)
\end{tabular} & 0.69 \\
\hline
\end{tabular}


Zahrul Atharinafi and Nurrohman Wijaya

\begin{tabular}{|l|l|}
\hline Variable & MSA \\
\hline Health Clinic Accessibility (Delta) & 0.64 \\
\hline Built-up Area (Growth, pct\%) & 0.71 \\
\hline
\end{tabular}

Before moving on to further analysis, we first perform a Kaiser-Meyer-Olkin test of the data, to judge whether the variables we have are suitable for factor analysis.

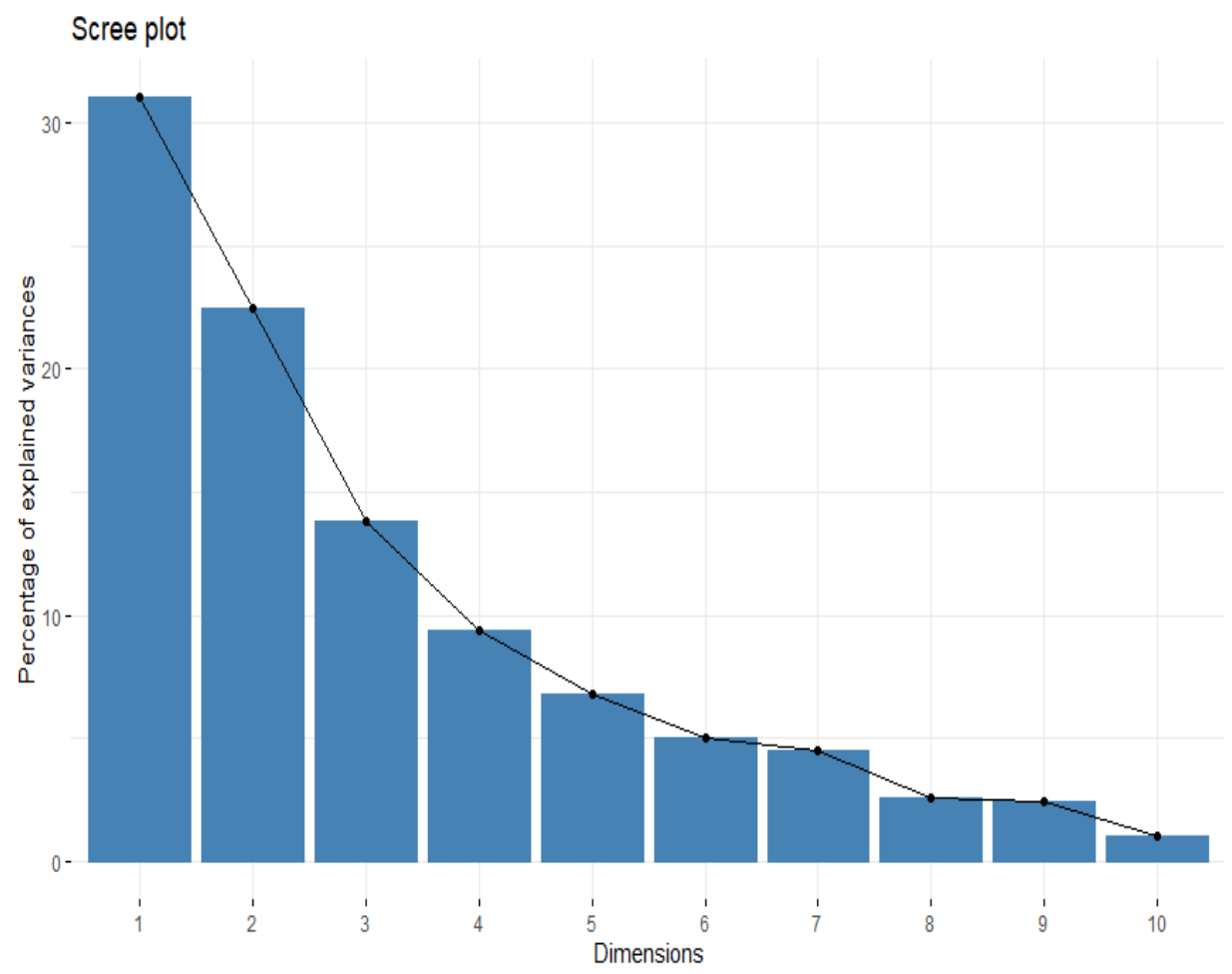

Figure 1. Scree Plot 


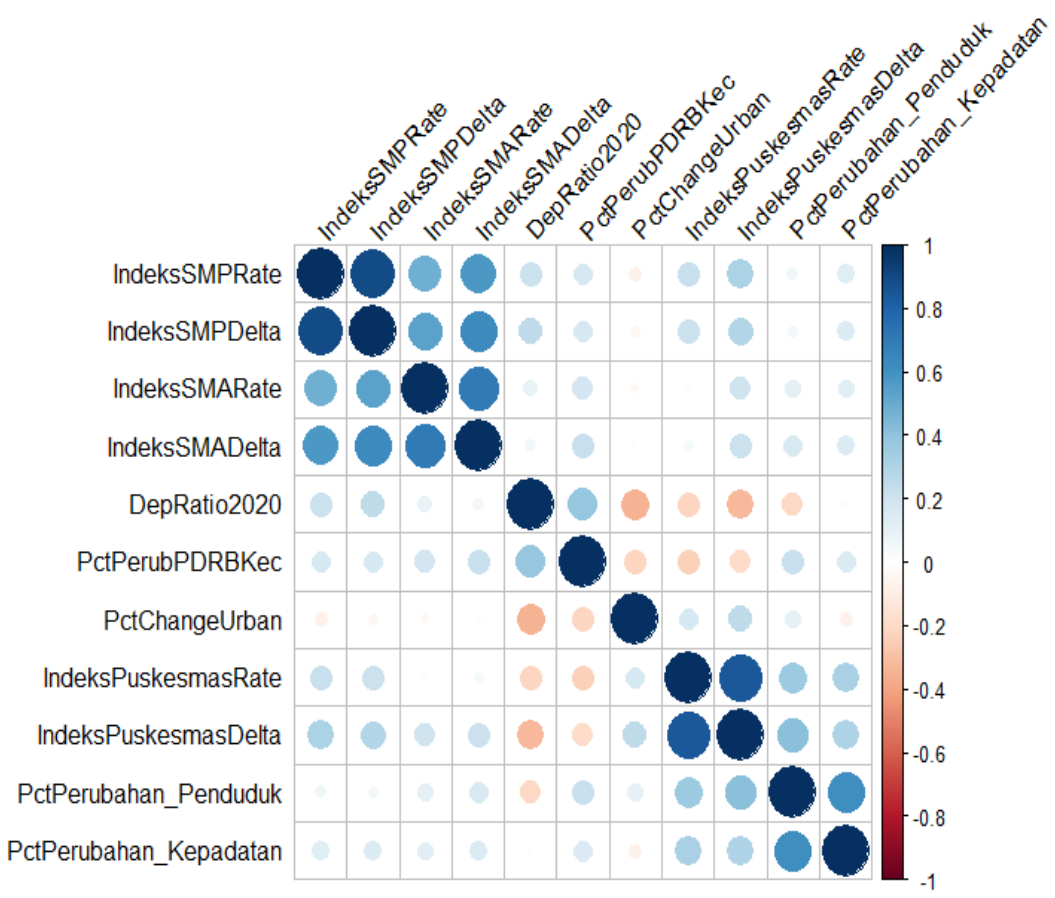

Figure 2. Correlation Plot

From eigenvalues higher than 1, we were able to extract 3 factors from the variables we have. The scree plot (Figure 1) shows that we have up to 3 factors underlying our observed variables; with 3 factors capable of explaining up to $57 \%$ of the total cumulative variance within observed data.

Table 3. Factor Loadings (Varimax)

\begin{tabular}{|c|c|c|c|}
\hline Item & $\begin{array}{l}\text { PA1 (Peri/ } \\
\text { Suburbanization) }\end{array}$ & PA2 (Stable/Core) & PA3 (Growth) \\
\hline $\begin{array}{l}\text { Population } \\
\text { Growth (\%) }\end{array}$ & 0.03 & 0.14 & 0.88 \\
\hline $\begin{array}{l}\text { Population } \\
\text { Density Growth } \\
(\%)\end{array}$ & 0.12 & 0.03 & 0.68 \\
\hline Dependency Ratio & 0.21 & -0.5 & -0.05 \\
\hline $\begin{array}{l}\text { Middle School } \\
\text { Accessibility } \\
\text { (Growth, pct \%) }\end{array}$ & 0.87 & 0.01 & 0.04 \\
\hline $\begin{array}{l}\text { HighSchool } \\
\text { Accessibility }\end{array}$ & 0.64 & 0.09 & 0.11 \\
\hline
\end{tabular}




\begin{tabular}{|c|c|c|c|}
\hline Item & $\begin{array}{l}\text { PA1 (Peri/ } \\
\text { Suburbanization) }\end{array}$ & PA2 (Stable/Core) & PA3 (Growth) \\
\hline \multicolumn{4}{|l|}{ (Growth, pct \%) } \\
\hline $\begin{array}{l}\text { Health Clinic } \\
\text { Accessibility } \\
\text { (Growth, pct \%) }\end{array}$ & 0.2 & 0.69 & 0.35 \\
\hline GRP Growth (\%) & 0.19 & -0.53 & 0.3 \\
\hline $\begin{array}{l}\text { Middle School } \\
\text { Accessibility } \\
\text { (Delta) }\end{array}$ & 0.93 & -0.01 & 0.03 \\
\hline $\begin{array}{l}\text { High School } \\
\text { Accessibility } \\
\text { (Delta) }\end{array}$ & 0.72 & -0.08 & 0.14 \\
\hline $\begin{array}{l}\text { Health Clinic } \\
\text { Accessibility } \\
\text { (Delta) }\end{array}$ & 0.35 & 0.8 & 0.38 \\
\hline $\begin{array}{l}\text { Built-up Area } \\
\text { (Growth, pct\%) }\end{array}$ & -0.06 & 0.38 & -0.01 \\
\hline
\end{tabular}

Table 4. Factor Score (weights)

\begin{tabular}{llll}
\hline Item & $\begin{array}{l}\text { PA1 (Peri/ } \\
\text { Suburbanization) }\end{array}$ & PA2 (Stable/Core) & PA3 (Growth) \\
\hline $\begin{array}{l}\text { Population } \\
\text { Growth (\%) }\end{array}$ & -0.099 & -0.117 & 0.707 \\
$\begin{array}{l}\text { Population } \\
\begin{array}{l}\text { Density Growth } \\
\text { (\%) }\end{array}\end{array}$ & -0.09 & -0.07 & 0.195 \\
$\begin{array}{l}\text { Dependency Ratio } \\
\text { Middle School }\end{array}$ & 0.003 & & \\
$\begin{array}{l}\text { Accessibility } \\
\text { Men }\end{array}$ & & -0.084 & 0.112 \\
\end{tabular}




\begin{tabular}{|c|c|c|c|}
\hline Item & $\begin{array}{l}\text { PA1 (Peri/ } \\
\text { Suburbanization) }\end{array}$ & PA2 (Stable/Core) & PA3 (Growth) \\
\hline \multicolumn{4}{|l|}{ (Growth, pct \%) } \\
\hline $\begin{array}{l}\text { High School } \\
\text { Accessibility } \\
\text { (Growth, pct \%) }\end{array}$ & 0.105 & -0.115 & $-0,003$ \\
\hline $\begin{array}{l}\text { Health Clinic } \\
\text { Accessibility } \\
\text { (Growth, pct \%) }\end{array}$ & -0.088 & -0.074 & -0.001 \\
\hline GRP Growth (\%) & 0.042 & -0.246 & 0.100 \\
\hline $\begin{array}{l}\text { Middle School } \\
\text { Accessibility } \\
\text { (Delta) }\end{array}$ & 0.614 & -0.039 & -0.127 \\
\hline $\begin{array}{l}\text { High School } \\
\text { Accessibility } \\
\text { (Delta) }\end{array}$ & 0.142 & -0.039 & 0.031 \\
\hline $\begin{array}{l}\text { Health Clinic } \\
\text { Accessibility } \\
\text { (Delta) }\end{array}$ & 0.199 & 0.913 & 0.138 \\
\hline $\begin{array}{l}\text { Built-up Area } \\
\text { (Growth, pct\%) }\end{array}$ & -0.028 & 0.073 & -0.057 \\
\hline
\end{tabular}

Based on factor loadings; factor 1 is highly correlated with increased school (Middle \& High School) accessibility. Development of school facilities (especially private schools) is typical of urbanizing/peri-urbanizing regions and therefore, might indicate the periurbanization of a district. Factor 2 is highly correlated with health clinic accessibility and slightly correlated with built-up area growth. Factor 3 meanwhile, is highly correlated with population growth variables and slightly correlated with health clinic accessibility. This might represent districts in the latter stages of urbanization; with growth having caught up to the point that would make it financially feasible to construct more than 1 puskesmas in a kecamatan-level district.

From the factor score weights, factor 1 is influenced by school facilities, factor 2 is influenced by healthcare accessibility and negatively influenced by GRP growth, whereas factor 3 is primarily influenced by population growth. For factor 2, a high negative score could indicate unplanned growth, as healthcare facilities aren't being built in line with population growth and urbanization. 


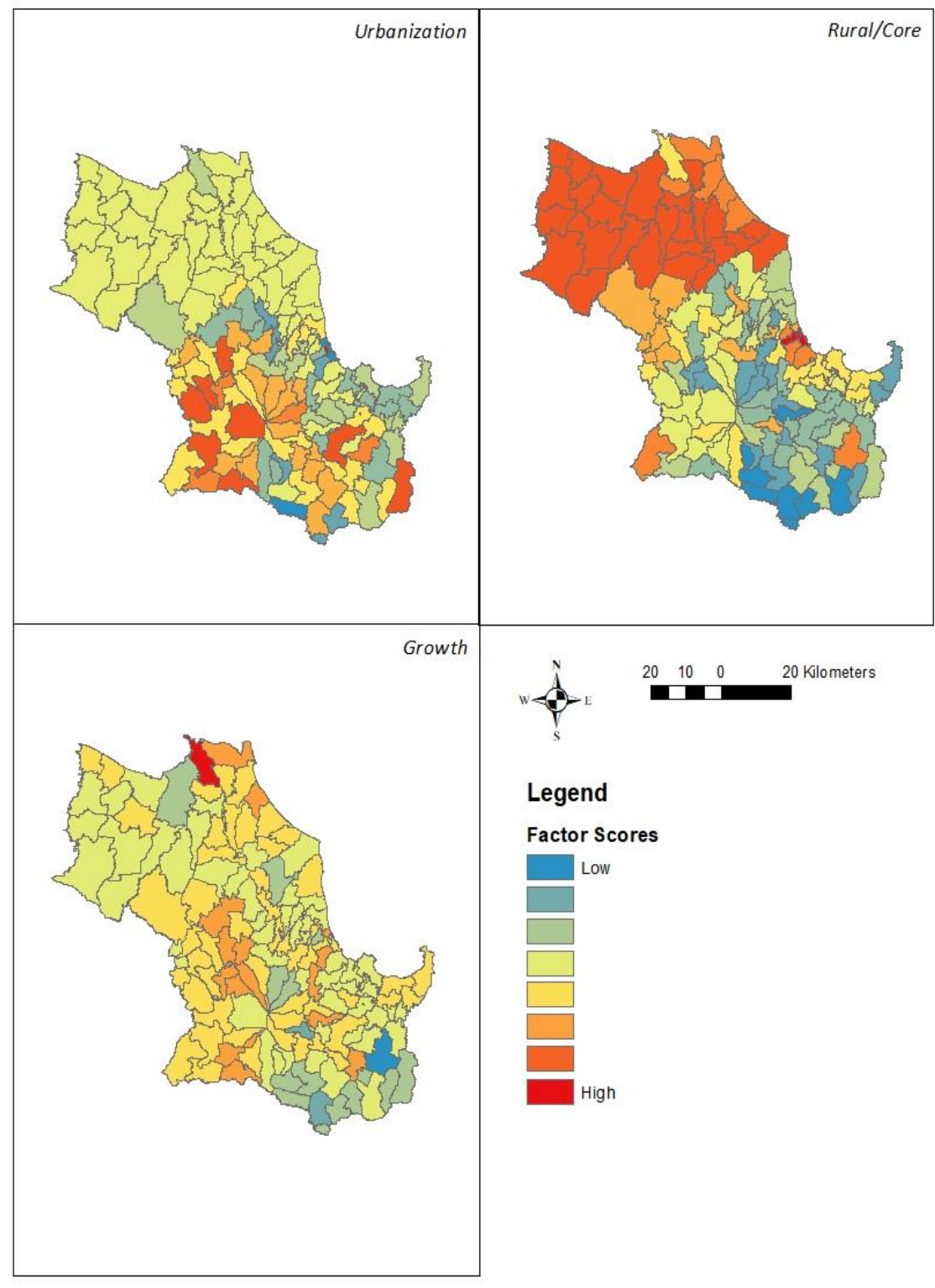

Figure 3. Factor Scores

By mapping factor scores from factor analysis, we can identify peri urbanization in Majalengka and some districts in Kuningan. Urbanization is strongest in western Majalengka and certain touristic districts in Kuningan. Development has been slowest in Indramayu and central Kota Cirebon, with Indramayu retaining its rural character whereas Kota Cirebon has reached its capacity for further development. Population growth, meanwhile, does not appear to correlate with peri-urbanization or development. With the limited variables used in this study and relatively low explanatory capacity of our factor analysis (3 factors explaining $57 \%$ of total variance), adding more variables may or may not improve this methodology, though we do recommend the use of more variables in further 
studies. Even then, we can still identify desakota patterns of urbanization, in which urbanization is driven by endogenous factors as opposed to urban sprawl from known urbanized cores (in this case, Kota Cirebon), with a belt of mostly non-urbanizing rural areas separating the urbanizing parts of Majalengka with Kota Cirebon. Other factors such as road networks and topology may also be considered as a spatial overlay over the maps of factor scores to further improve the analysis of urbanization tendencies and urban-rural linkages.

\subsection{K-Means Clustering}

Table 5. Cluster Means

\begin{tabular}{|c|c|c|c|c|}
\hline Item & $\begin{array}{l}\text { Cluster } 1 \\
\text { (Underdevelo- } \\
\text { ped, } \\
\text { urbanizing) }\end{array}$ & $\begin{array}{l}\text { Cluster } 2 \\
\text { (Urbanizing, } \\
\text { rapid) }\end{array}$ & $\begin{array}{l}\text { Cluster } 3 \\
\text { (Rural) }\end{array}$ & $\begin{array}{l}\text { Cluster } 4 \\
\text { (Urbanizing) }\end{array}$ \\
\hline $\begin{array}{l}\text { Population } \\
\text { Growth (\%) }\end{array}$ & 10.479 & 8.727 & 5.701 & 10.072 \\
\hline $\begin{array}{l}\text { Population } \\
\text { Density } \\
\text { Growth (\%) }\end{array}$ & 8.535 & 8.938 & 1.691 & 9.724 \\
\hline $\begin{array}{l}\text { Dependency } \\
\text { Ratio }\end{array}$ & 39.96 & 47.37 & 45.229 & 47.37 \\
\hline $\begin{array}{l}\text { Middle School } \\
\text { Accessibility } \\
\text { (Growth, pct } \\
\%)\end{array}$ & -5.430 & 371.189 & -6.618 & 47.617 \\
\hline $\begin{array}{l}\text { High School } \\
\text { Accessibility } \\
\text { (Growth, pct } \\
\% \text { ) }\end{array}$ & -5.949 & 797.25 & -14.5621 & 119.949 \\
\hline $\begin{array}{l}\text { Health Clinic } \\
\text { Accessibility } \\
\text { (Growth, pct } \\
\%)\end{array}$ & 3.736 & -9.135 & -74.04 & -47.034 \\
\hline $\begin{array}{l}\text { GRP Growth } \\
(\%)\end{array}$ & 60.09 & 100.27 & 146.43 & 172.245 \\
\hline $\begin{array}{l}\text { Built-up Area } \\
\text { (Growth, } \\
\text { pct\%) }\end{array}$ & 43.285 & 19.59 & 19.03 & 8.34 \\
\hline Size & 34 & 2 & 55 & 43 \\
\hline
\end{tabular}




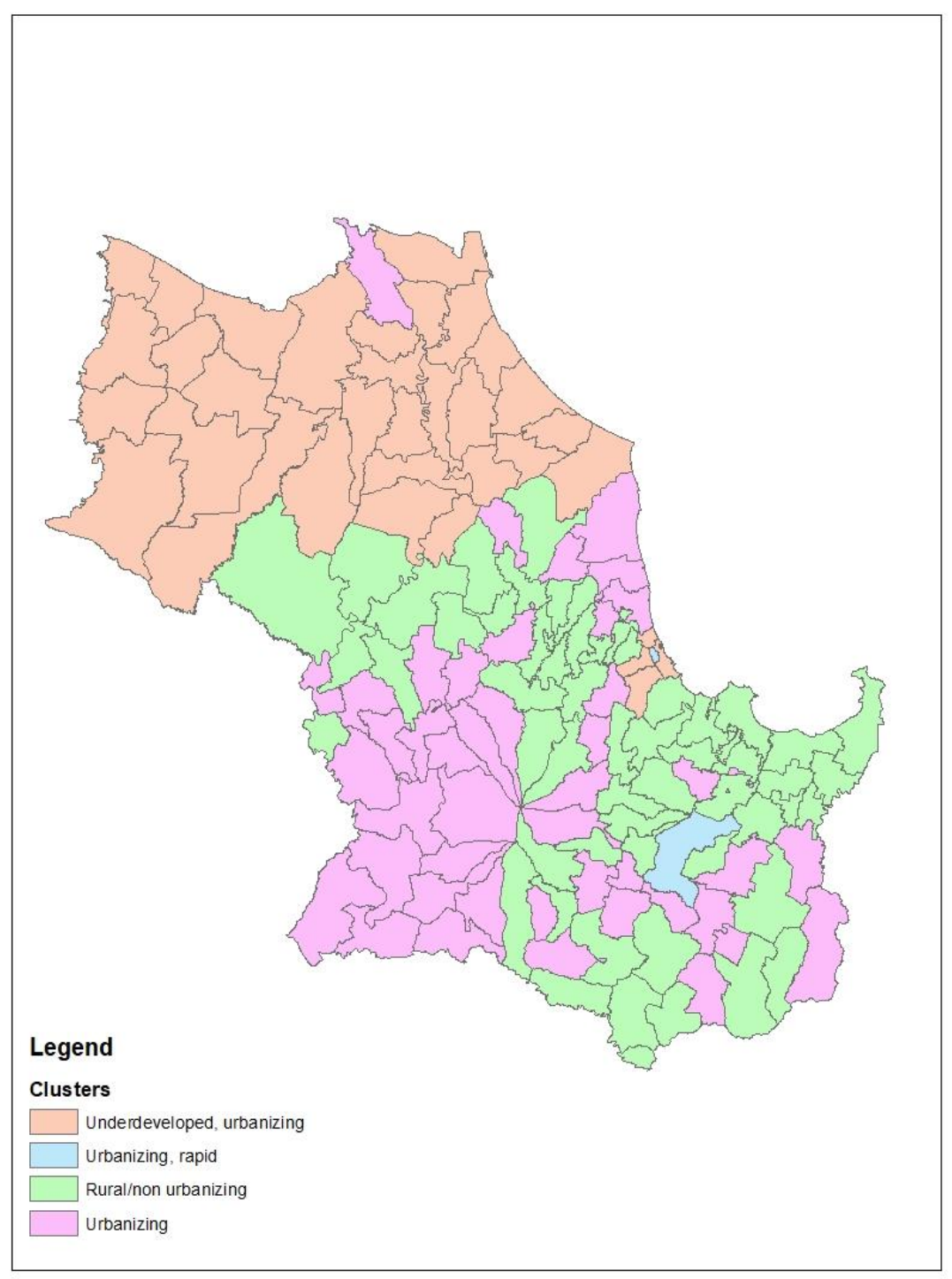

Figure 4. Clusters, mapped

Based on the results of k-means clustering, 3 main clusters are identified with 1 outlier cluster. Cluster 1 consists of most districts (kecamatan) in Kabupaten Indramayu and some in and around the core of Kota Cirebon. This cluster represents regions that have seen low socioeconomic growth but are otherwise growing in population density and built-up area. Cluster 2 is an outlier cluster consisting of 2 kecamatan with extremely rapid school construction in the 10 years between 2010 and 2020 and could be merged into Cluster 4 . Cluster 3 consists of rural districts with low population growth, minimal construction of new public facilities but still able to experience substantial GRP growth. Cluster 4 consists of potentially "desakota" characteristics, having the highest average GRP growth and primarily defined by the rapid construction of new schools. Most interestingly, Cluster 4 also includes newly industrializing districts in Kabupaten Majalengka and Kabupaten Cirebon - more schools could either be a consequence or the reason for industrialization (Carl, 2009) following lessons from the Industrial Revolution in developed countries. 


\subsection{Discussion}

In Southeast Asian countries, the process of urbanization is influenced not only by the expansion of existing conurbations but also through organic development in the hinterlands surrounding a conurbation. The latter of which was then given the term "desakota" by McGee (1991); a portmanteau of Indonesian words "desa" (village) and "Kota" (city), reflecting the nature of urbanized pockets in otherwise rural areas.

Even so, urbanization in hinterland areas is still dependent on nearby cities and the presence of ample transportation networks, allowing cheaper, free movement of goods and labor from rural hinterlands to the city, as simulated by Xie et al. (2005). The circular movement of people between rural hinterland regions and cities, enabled by free movement, can also allow rural inhabitants to find work in cities and commute intermittently, leaving behind family in the village (Hugo, 1982; Olsson, 2012; Kim, 2015). Overseas migrant workers from rural areas sending remittances home are a significant population in our study area, in particular, Indramayu (Iqbal, 2015; Mulyana, 2017), which can then generate demand for non-agricultural economic activities from increased consumer spending in the area.

In our study, we have identified a cluster of peri-urbanization following the desakota model (McGee, 1991), primarily in Majalengka, parts of Kabupaten Cirebon, and parts of Kuningan. In Majalengka and Kabupaten Cirebon, this urbanization is the result of mass industrialization from government policies (see RTRW Majalengka 2011 - 2031 \& and RTRW Kabupaten Cirebon 2018 - 2038), and development of transportation networks favoring the development of industrial clusters in Majalengka and Kabupaten Cirebon (Cikopo-Palimanan Toll Road). Schools are a necessary component of industrialized society, to provide better-qualified workers - hence the rapid increase in new schools, especially private schools, as a response to a demand for more education. From factor analysis, this cluster of "desakota" development corresponds to high scores in peri-urbanization related indices - tied to the development of new educational facilities, corroborating wi

In Indramayu meanwhile, we have identified population increases and built-up area, yet negligible economic growth. Indramayu is a known oil and gas producer in which oil and gas is a significant contributor to its Gross Regional Product (BPS Kabupaten Indramayu, 2020), and therefore, may or may not have distorted the results of our analysis. Also in the same cluster as Indramayu (Cluster 1) are some kecamatan in the old city core of Kota Cirebon, which understandably did not grow as much as urbanizing districts elsewhere with not much space to build more facilities.

Cluster 3 includes districts that have seen less growth compared to districts from other clusters, in terms of demographics and land cover change. These are mostly rural districts that are likely to remain rural for the time being and are relatively underdeveloped facilities-wise. This cluster is associated with low scores in "peri-urbanization", an indication of their underdevelopment relative to neighboring districts.

An interesting point to note from the results of our study is that urbanization linkages with Kota Cirebon could be described as weak - with industrialization in Majalengka perhaps being more influenced by Bandung and government policies than Cirebon, being at the center of the Bandung-Cirebon Growth Corridor (RTRW Provinsi Jawa Barat 2009 - 2029). Also in Majalengka, is the development of Kertajati Aerocity, which may stimulate industrial development centered on Majalengka rather than Cirebon. As opposed to other centers of urbanization in West Java (Bandung Raya, Bodebekarpur), Cirebon lacks pull factors to create significant urban-rural linkages. It is not a national (Jakarta) nor a provincial capital (Kota Bandung). It lacks strong industrial clusters; such as the automotive industry in periurban Bodebekarpur (Hudalah, 2013). Cirebon does have a rattan furniture industry, albeit one that has been in decline in recent times (Nangoy, 2011). Fahmi et al. (2014), notes that foreign direct investment in Cirebon has otherwise been minimal; The core of Cirebon (Kota 
Cirebon), as they describe, mostly functions as a regional center for trade and retail activities. In the same paper, Fahmi et al (2014) suggest that a major component of growth in the core of Cirebon is that there is a significant proportion of residents who commute to and from Jakarta, effectively making Cirebon an edge city of Greater Jakarta.

The strength of desakota development in Majalengka is underlined by the development of supporting, large-scale infrastructure development within Majalengka. Such infrastructure development can create a completely new growth pole from the ground up, especially if the planned Kertajati Aerocity can live up to its potential as a cargo and aviation industry hub (Tjahjono \& Yuliawati, 2020). Similar megaprojects are widespread throughout Indonesia, as part of its national regional planning and development planning policies, and underline the second agenda of Indonesia's 5-year development plan - the creation of new growth poles ("Pusat pertumbuhan") in underdeveloped regions as means of regional economic redistribution. (RPJMN 2020 - 2024). Overlaying clusters and factor scores with influencing infrastructural development may be a good method that can be utilized to align urban-rural linkages with infrastructure networks to identify whether infrastructure networks influence the strength of urban-rural linkages.

\section{Conclusion and Recommendation}

Using a combination of factor analysis and K-Means Clustering, with growth-based data, is a useful method of identifying and evaluating urban-rural interactions in an area. Urban-rural interactions are highest in rapidly urbanizing areas and lowest in areas that were already urban and cannot expand further, or areas that will remain rural for the time being. However, using the data we have, we cannot reliably assess the strength of urbanrural interactions, solely from the replicating factor analysis as performed by $\mathrm{Li}$ (2012), due to our differing variables. Most importantly, we were unable to identify increases in nonagriculture employment as data from Badan Pusat Statistik regarding non-agriculture unemployment is either missing or not publicly available.

At the Kecamatan scale, we were also unable to gather economic data, as this is aggregated at the Kabupaten level. We had to extrapolate GRP per kecamatan based on population following Fajar (2014), which may have influenced the accuracy of our findings. Additionally, evaluating detailed economical differences between each kecamatan (ie. percentage of non-agricultural contribution towards GRP) as per Li (2012) is not possible to assess, as Badan Pusat Statistik no longer publishes this data at this scale. We strongly recommend adding a percentage of non-agricultural employment and a percentage of nonagricultural contribution towards GRP, should they ever be available for us. Adding both variables could improve the ability to identify and also better evaluate urban-rural linkages on a socioeconomic level.

Percentage of non-agricultural employment and percentage of non-agricultural contribution towards GRP are both important variables to assess and identify desakota processes, as desakota development itself is not necessarily expansive (McGee, 1991; Hudalah et al., 2020) in a manner that can be identified through the land cover.

For practicing development and regional planners in Indonesia, especially at provincial scale or national scale, similar to $\mathrm{Li}$ (2012) in terms of scale, perhaps it is still possible to utilize this factor analysis and K-Means Clustering-based methodology in a practical situation. Practicing development planners at the Kabupaten scale can perform a similar analysis to evaluate urban-rural linkages should they have the required additional data. Using more data (ie. poverty rate, unemployment rate) may or may not improve the analysis and is something to consider for future research and development of this methodology for Indonesian and Southeast Asian use cases. In any case, it does have the potential to delineate metropolitan areas, as well as identify potentially urbanizing areas. 
There are shortcomings of utilizing this methodology for evaluating urban-rural linkages, as it cannot accurately identify the magnitude of a linkage, it merely helps to identify the existence of an urban-rural linkage. We also could not assess whether a newly urbanizing area is a result of nearby urban/metropolitan cores, or completely independent from its influence. Usage of factor analysis and K-Means Clustering of growth-rate oriented variables (in particular, as a methodology for delineation of metropolitan areas and urbanizing areas) should be overlaid and integrated with additional analysis of transportation networks, outside influencing factors, and morphological structures. Using more data (Budiyantini \& Pratiwi, 2016) may improve a researchers' ability to analyze urbanrural linkages with this method, but requires further testing whether more data would lead to improved model outcomes.

\section{References}

Bao, S., Henry, M., \& Barkley, D. (2004). Identifying Urban-Rural Linkages: Tests for Spatial Effects in the Carlino-Mills Model. In Advances in Spatial Econometrics: Methodology, Tools, and Applications. Springer.

BAPPEDA Kabupaten Majalengka. (2012). RTRW Kabupaten Majalengka 2011 -2031.

Bappelitbangda Kabupaten Cirebon. (2018). RTRW Kabupaten Cirebon 2018-2038.

BPS Kabupaten Indramayu. (2021). Produk Domestik Regional Bruto Kabupaten Indramayu Menurut Lapangan Usaha 2016-2020.

Budiyantini, Y., \& Pratiwi, V. (2016). Peri-Urban Typology of Bandung Metropolitan Area. Procedia Social and Behavioral Sciences, 227.

Carl, J. (2009). Industrialization and Public Education: Social Cohesion and Social Stratification. In International Handbook of Comparative Education.

Cattell, R. B. (1966). The Scree Test for the Number of Factors. Multivariate Behavioral Research, 1(2).

Costa, D., Hur, S., Kehoe, T. J., Raveendranathan, G., \& Ruhl, K. J. (2016). The Stages of Economic Growth Revisited. Minneapolis Federal Reserve Bank.

Fabrigar, L., Wegener, D. T., MacCallum, R. C., \& Strahan, E. J. (1999). Evaluating the use of Explanatory Factor Analysis in Psychological Research. Psychological Methods, 4(3).

Fahmi, F. Z., Hudalah, D., Rahayu, P., \& Woltjer, J. (2014). Extended suburbanization in small and medium-sized cities: The case of Cirebon, Indonesia. Habitat International, 42.

Harrell Jr., F. E. (2021). The r package "hmisc."

Hill, B. D. (2011). The Sequential Kaiser-Meyer-Olkin Procedure as an alternative for determining the number of factors in Common Factor Analysis: A Monte Carlo Simulation. Oklahoma State University.

Hodder, R. (2000). Development Geography (1st ed.). Routledge.

Hudalah, D., Octifanny, Y., Talitha, T., Firman, T., \& Phelps, N. A. (2020). From Metropolitanization to Megaregionalization: Intentionality in the Urban Restructuring of Java's North Coast, Indonesia. Journal of Planning Education and Research.

Hugo, G. J. (1982). Circular Migration in Indonesia. Population and Development Review, 8(1).

Kementerian PPN/Bappenas. (2020). Rencana Pembangunan Jangka Menengah Nasional $2020-2024$. 
Kim, S. M. (2015). An Empirical Analysis on Urban-Rural Linkage in Mumbai Metropolitan Area. The Journal of Development Practice, 2.

Lewis, B. D. (2014). Urbanization and Economic Growth in Indonesia: Good Neres, Bad Neres and (Possible) Local Government Mitigation. Regional Studies, 48(1).

Li, Y. (2012). Urban-rural interaction patterns and dynamic land use: Implications for urban-rural integration in China. Regional Environmental Change, 12.

Lynch, K. (n.d.). Rural-Urban Interaction in the Developing World (1st ed.). Routledge.

McGee, T. (1991). The Emergence of "Desakota" Regions in Asia: Expanding a Hypotheses. University of Hawaii Press.

McGranahan, G., \& Satterthwaite, D. (2014). Urbanization concepts and trends. IIED Working Paper. International Institute of Economic Development.

Mulyana, S., Zein, D., \& Setiaman, A. (2017). Communication Patterns of Woman Migrant Workers at Sliyeg District in Indramayu-West Java. Communication Journal of Indonesian Association of Communications Scholars, 2(2).

Mutizwa-Mangiza, N. (1999). Strengthening rural-urban linkages. Habitat Debate, 5(1).

Nangoy, O. M. (2011). Terpuruknya Industri Mebel Rotan Cirebon. Humaniora, 2(1).

Olsson, J. (2012). Rural-Urban spatial interaction in the global south: Long-Distance Mobility Changes, Desires and Restrictions over two decades in the rural Philippines. Geografika Annaler: Series B Human Geography, 94(3).

Phan, T. N., Kuch, V., \& Lehnert, L. W. (2020). Land Cover Classification using Google Earth Engine and Random Forest Classifier-The Role of Image Composition. Remote Sensing, $12(15)$.

Pryor, R. (1971). Defining The Rural-Urban Fringe. In The Internal Structure of the City: Readings on Space and Environment. Oxford University Press.

Pull and Push Factors of Indonesian Women Migrant Workers from Indramayu (West Java) to Work Abroad. (2015). Mediterranean Journal of Social Sciences, 6(5).

Qadeer, M. A. (2000). Ruralopolises: The spatial organizations of the residential land economy of high-density rural regions in South Asia. Urban Studies, 37(9).

Revelle, W. (2021a). How to: Use the psych package for Factor Analysis and data reduction.

Revelle, W. (2021b).

Rostow, W. W. (1960.). The Stages of Economic Growth: A Non-Communist Manifesto. Cambridge University Press.

Setiadi, R., Artiningsih, A., Sophianingrum, M., \& Satriani, T. (2020). The dimension of ruralurban linkage of food security assessment: An Indonesian case study. Asian Geographer.

Setyono, J. S., Yunus, H. S., \& Giyarsih, S. R. (2016). The Spatial Pattern of Urbanization and Small-Cities Development in Central Java: A Case Study of SemarangYogyakarta-Surakarta Region. Geoplanning: Journal of Geomatics and Planning, 3(1).

Sidhu, N., Pebesma, E., \& Camara, G. (2018). Using Google Earth Engine to detect land cover change: Singapore as a use case. European Journal of Remote Sensing, 51, 2018.

Smailes, A. E. (1961). The Geography of Towns (2nd ed.). Routledge.

Surya, B., Ahmad, D. N. A., Sakti, H. H., \& Sahban, H. (2020). Land Use Change, Spatial Interaction, and Sustainable Deve. Land, 9(3).

Wei, T., \& Simko, V. (2021). R package "corrplot." 
Zahrul Atharinafi and Nurrohman Wijaya

Xie, Y., Batty, M., \& Zhao, K. (2005)). Simulating emergent urban form: Desakota in China. In CASA Working Papers 95. Centre for Ad vanced Spatial Analysis (UCL).

Yunus, H. S. (2008). Dinamika Wilayah Peri-Urban Masa Depan Kota. Pustaka Pelajar. 